\title{
Interactions between Entomopathogenic Nematodes and Entomophagous Insects
}

\author{
Mohamed Samir Tawfik Abbas \\ Plant Protection Research Institute, Agricultural Research Centre, Giza, Egypt \\ Email: samra_mst@hotmail.com
}

How to cite this paper: Abbas, M.S.T. (2020) Interactions between Entomopathogenic Nematodes and Entomophagous Insects. Advances in Entomology, 8, 147-157. https://doi.org/10.4236/ae.2020.84011

Received: July 13, 2020

Accepted: October 10, 2020

Published: October 13, 2020

Copyright $\odot 2020$ by author(s) and Scientific Research Publishing Inc. This work is licensed under the Creative Commons Attribution International License (CC BY 4.0).

http://creativecommons.org/licenses/by/4.0/

\begin{abstract}
The objective of this review article is to clarify the different interactions between entomopathogenic nematodes, as bio-control agents, against other bio-control agents (parasitoids and predators) proposed by the researchers. Thus, it gives clear information concerning the potential of combining them as a part of Integrated Pest Management (IPM) programs against insect pests. Some laboratory studies showed that the treatment of predacious insects by entomopathogenic nematodes (EPNs) at different concentrations can infect and kill the treated larva, nymphs and adults of predators. The percentages of mortality were found to be high (up to $100 \%)$, moderate $(15 \%-35 \%)$ or low $(3 \%-7 \%)$. Other studies revealed the resistant of treated predators to nematode-infection. Some predators that were offered infected prey avoid feeding on such prey and, in contrast, the soil predators (ants and mites) consumed the offered cadavers as well as the infective juvenile of the nematodes and did not show any detrimental effects. Mostly, parasitoids cannot complete their development inside or on nematode-infected hosts if parasitism occurs before or early after infection. The parasitoid females may avoid laying eggs in the infected hosts or cannot discriminate between healthy and infected hosts. A field study demonstrated that applying EPNs combined with the predator, Labidura riparia significantly reduced the population of the target pest compared to the nematode or the predator alone. Also, two field experiments indicated that the combination of parasitoids and nematodes can be successful for insect pest management.
\end{abstract}

\section{Keywords}

Entomopathogenic Nematodes, Steinernema, Heterorhabditis, Parasitoids, Predators, Entomophagous Insects

\section{Introduction}

Combination of entomopathogens and other biological control agents (parasi- 
toids and predators) can be synergistic, additive or antagonestic depending on the specific biological control agents and their rate, timing of application and host species [1]. Synergestic interactions result in a higher mortality than the combined individual mortalities of the pest population. Additive interactions occur if the natural enemies do not interact and, thus, the total level of mortality is equivalent to the combined individual mortalities caused by each agent. The antagonistic interactions occur if the total mortality is less than when either natural enemy acts alone [2].

\section{Entomopathogenic Nematodes (EPNs)}

The free-living, non-feeding $3^{\text {rd }}$ stage infective juveniles (IJs) of the entomopathogenic nematodes (EPNs) of the genera Steinernema and Heterorhabditis in the (families Steinernematidae and Hetrorhabditidae, respectively) possess attributes of both insect parasitoids or predators and microbial pathogens. Like parasitoids/predators, they have chemoreceptors and are motile, in soil, looking for suitable host. Like pathogens, they are highly virulent, killing the host quickly and can be cultured easily in vivo and in vitro [3]. The members of both families are associated with mutualistic bacteria of the genera Xenorhabdus (for Steinernematidae) and Photorhabdus (for Heterorhabditidae) [4]. IJs can locate the host by detecting the insect excretory products, carbon dioxide levels, temperature gradients and movement of the host. The IJs then penetrate the host through natural openings; mouth, anus or spiracles, and in addition, IJs in heterorhabditids possess a tooth that enables them to penetrate the host through the cuticle of certain insects. Once they enter the hemocoel, they release the bacteria which multiply and kill the host by cepticaemia [5]. EPNs have positive characters including their broad host range, safety to vertebrates, plants and non-target organisms [6], exempting from registration in many countries, easily applied using a standard spray equipment [5], compatible with many chemical and bio-pesticides and amenable to genetic selection [7]. In field application, commercially, a dose of $2.5-5 \times 10^{9} \mathrm{IJs} / \mathrm{ha}$ was recommended to give effective control comparable to chemical insecticides [8]. The EPNs have great potential to be used in integrated pest management programs. They are more specific, proven to be safe and effective alternatives to chemical pesticides. The susceptibility of insect pests varies depending on the selectivity and applied rates of EPN species. Location of the host by IJs within the soil is one of the most important factors where their movements are affected by temperature and oxygen levels. Temperature, moisture, aeration and soil type, the species of EPN, age of target insects and soil fauna are important factors affecting the activity of EPNs.

\section{Parasitoids and Predators}

Parasitoids and predators are among the biological control agents that play an important role, naturally, against agricultural pests infesting field crops, vegetables, orchards and ornamentals. They constitute a considerable part within IPM programmes which include suitable timing of plantation, suitable agricultural practices, using biological control agents (parasitoids, predators and entomopa- 
thogens) and finally selective chemical insecticides if needed [9].

\section{Interactions between EPNs and Predators}

\subsection{Impact of EPNs on Treated Predators}

\subsubsection{Laboratory Experiments}

The nematode, Steinernema kraussei did not infect the larvae of 2 dipteran predators of the sawfly, Cephaleia abietis (L.): Thereva handlirschi Krober (Fam. Therevidae) and Rhagio notatus (Meigen) (Fam. Rhagionidae) when treated with a concentration of $5000 \mathrm{IJs} / \mathrm{ml}$ in Petri-dishes [10]. At a concentration of 20 $\mathrm{IJs} / \mathrm{cm}^{2}$ in Petri-dishes, the immature and adult stages of the earwig, Labidura riparia Pallas (Dermaptera: Labiduridae) were resistant to infection by Heterorhabditis bacteriophora Poinar and S. carpocapsae (Weiser) [11]. Also, S. scapterisci Nguyen \& Smart did not cause mortality in treated European earwig, Furficula auricularia (L.) [12]. Also, Dalotia coriaria (Kratz) (Col., Staphilinidae), a common predator of the flower thrips, Frankliniella occidentalis (Pergande) was not susceptible to $S$. feltiae at concentrations of 12,25 and $50 \mathrm{IJs} / \mathrm{cm}^{2}$ [13]. Similarly, investigating the pathogenicity of 3 commercial nematode species to adults and $3^{\text {rd }}$ instar larvae of $D$. coriaria at 3 concentrations $\left(50,100\right.$ and $200 \mathrm{IJs} / \mathrm{cm}^{2}$ ) showed that mortality percentages for the 3 nematode species did not differ significantly from the control [14]. Testing the impact of H. bacteriophora on eggs, larvae and adults of Chrysoperla zastrowi sillemi (Espen. Peterson) sprayed with the nematode suspension containing 5000 IJs (10 eggs or larvae or adults /Petri-dish) showed that the nematode did not affect, significantly, egg-hatching and survival of larvae or adults of the predator. Microscopic examination of the treated eggs, larvae and adults exhibited no morphological or physical changes [15]. Similarly, S. carpocapsae did not cause mortality in the 2 mirid predators, Macrolophus pygmaeus Rambur and Nesidiocoris tenuis Reuter when treated in pots at a concentration of $50 \mathrm{IJs} / \mathrm{cm}^{2} / 5$ nymphs or adults [16].

In contrast to the above mentioned studies, the staphylinid predator, Philonthus sp. was found to be infected with $H$. bacteriophora and $S$. carpocapsae and the adult was less susceptible than the $3^{\text {rd }}$ larval instar [8]. Also, a high mortality of the coccinellid, Coccinella undecimpunctata (L.) was caused by $S$. carpocapsae and H. taysearae [17]. The pathogenicity of EPNs, S. carpocapsae (Weiser), $S$. feltiae (Filipjev) and Heterorhabditis bacteriophora Poinar was evaluated against the aphid predator, Aphidoletis aphidimyza (Rondani) (Dipt.: Cecidomyiidae) at 3 concentrations; 100, 1000 and 10,000 IJs/Petri-dish/10 larvae. The results showed that percent mortality in the treated larvae at the 3 tested concentrations ranged $33 \%-92 \%$ by $S$. carpocapsae, $20 \%-78 \%$ by $S$. feltiae and $9 \%-93 \%$ by $H$. bacteriophora [18]. Similarly, the efficacy of 3 species of EPNs was studied against larvae of the coccinellid, Adalia bipunctata (L.) and the chrysopid, Chrysoperla carnea Steph. at concentrations of 500, 2500 and $5000 \mathrm{IJs} / \mathrm{ml} / 20$ larvae. Percent mortality in A. bipunctata larvae ranged $84 \%-97 \%$ by $S$. feltiae, $79.5 \%-100 \%$ by $S$. carpocapsae and $43.6 \%-98 \%$ by $H$. bacteriophora. The re- 
spective values for $C$. carnea were $42 \%-66 \%, 90 \%-100 \%$ and $36.5 \%-65.8 \%$ [19]. At a concentration of $25 \mathrm{IJs} / \mathrm{cm}^{2}$ in Petri-dishes, $S$. carpocapsae caused $84.3 \%$ mortality in the European earwig, F. auricularia 48 h post treatment [20].

\subsubsection{Semi-Field and Field Experiments}

A field experiment revealed that $S$. kraussei did not cause detrimental effect on the populations of the dipteran predators of the sawfly, Cephaleia abietis (L.). The predators were Thereva handlirschi and T. valida Flekr (Fam. Therevidae) and Rhagio notatus and R. scolopacea (L.) (Rhagionidae) [10]. Similarly, in a cabbage field experiments, it was found that $S$. carpocapsae and $H$. bacteriophora did not affect the numbers of the earwig, Labidura riparia Pallas and other non-target soil arthropods in comparison with the untreated cabbage [11]. The combined releases of the predatory mite, Hypoaspisa culeifer (Canestrini) (Acari: Laelapidae) and two nematode species, $H$. bacteriophora and $S$. feltiae was evaluated against soil-dwelling stages of the thrips, Frankliniella occidentalis (Pergande) in pots [21]. The results indicated that $H$. culeifer reduced the proportion of adult thrips emergence by $46 \%$ in comparison with the control. Also, $S$. feltiae and $H$. bacteriophora reduced adult thrips emergence by $46 \%$ and $61 \%$, respectively. Significant lower emergence \% of adult thrips was obtained by combined treatments with the nematodes and the predatory mite, than individual application of the nematodes or the predator. In a greenhouse experiment, $S$. carpocapsae and $H$. bacteriophora were applied at concentrations of 25 and 250 IJs $/ \mathrm{cm}^{2}$ of soil (in pots) against aphids treated with $3^{\text {rd }}$ instar larvae of the predator, Aphidoletis aphidimyza (Ronden) [18]. S. carpocapsae caused $30 \%$ and $67 \%$ mortality at the 2 concentrations, respectively, in the larvae of the predator, A.aphidimyza compared to $49 \%$ and $81 \%$ mortality by $H$. bacteriophora. The compatibility of soil-dwelling predacious mites with $S$. feltiae at a concentration of $50 \mathrm{IJs} / \mathrm{cm}^{2}$ for controlling the thrips, F. occcidentalis was investigated in pots [22]. The predacious mites were Stratiolaelaps scimitus (Womersley) and Gaeolaelaps gillespiei Beaulieu (Acari: Laelapidae). The results showed that $S$. scimitus was not significantly affected by $S$. feltiae while $G$. gillespiei was adversely affected (57.5\% mortality).

\subsection{Discrimination between Healthy and Nematode-Infected Prey}

The earwigs were found to have the ability to avoid feeding on nematode-infected prey [23]. Also, the third larval instar and adults of tha carabid predator, Calosoma granulatum (Coleoptera), avoided feeding on Spodoptera frugiperda larvae infected with $H$. amazonensis [24]. When the predator $1^{\text {st }}$ instar larvae had access to the infected cadavers as food, most of them died within 6 days of feeding.

\subsection{EPNs as Prey for Predacious Insects and Mites in Soil}

The workers of the ant species (Fam. Formecidae): Linepithema humile (Mayer), Veromessor Andrei (Mayr), Pheidole vistana Forel, Formica pacifica Francoeur, 
and Monomorium ergatogyna Wheeler were found to feed on steinernematid-killed insects in soil but did not feed or fed very little on heterorhabditid-killed insects [25]. In addition, when L. humile was offered steinernematid-killed insects, it attacked $70 \%-80 \%$ of such insects compared to $5 \%-35 \%$ when offered heterorhabditid-killed insects. When 6-day old nematode-killed larvae of Ceratitis capitata (Wied) (with emerging IJs) were exposed to the mite, Sancassania polyphullae Oudenmans (Acari: Acaridae), the cadavers were consumed along with $96 \%$ of the emerging IJs [26]. The authors suggested that this fact could negatively impact the role of EPNs as biological control agent.

The effects of different soil arthropods on EPNs were studied under laboratory conditions as some predacious insects in soil may consume cadavers of nematode-killed insects [27]. The tested predators were offered $S$. feltiae and $H$. bacteriophora -infected larvae of Galleria mellonella (L.). The studies showed that: a. All tested nymphs and adults of the American cockroach, Periplaneta Americana (L.) (Fam. Blattidae) and the cricket, Gryllus bimaculatus De Geer (Orthoptera: Gryllidae) consumed Steinernema- and Heterorhabditis-killed Galleria larvae one day post infection. $89 \%$ and $58 \%$ of the 2 tested insects, respectively, consumed the infected larvae at 2-day post-infection. b. Labidura riparia adults, however, partly consumed only Steinernema-infected larvae at 2-day post-infection. None of the three tested insects consumed the nematode-killed larvae at 3-day post infection. c. The predacious mite, Sancassania polyphyllae consumed nematode-killed insects but did not consume free-living IJs in the soil environment. d. The ant, Tetramorium chefketi Forel (Hym.: Formicidae) consumed the $S$. feltiae-killed larvae but not those killed by $H$. bacteriophora.

\section{Interactions between EPNs and Parasitoids}

\subsection{Laboratory Experiments}

\subsubsection{Effect on Developmental Stages of Parasitoids inside Their Hosts}

$H$. indica did not affect percent emergence of Trichogramma chilonis and T. japonicum Ashmead in treated parasitized eggs of Corcyra cephalonica Stainton [28]. The same results were obtained by using $H$. bacteriophora [15].

Larvae of the tachinid parasitoid, Myxecoristops sp. did not complete its development in parasitized sawfly, Cephaleia abietis (L.) larvae treated with Steinernema kraussi [10]. Also, the tachinid parasitoid, Compsilura concinnata (Meigen) proved to be susceptible to $N$. carpocapsae and its associated bacterium, Xenorhabdus nematophilus [29]. In addition, the death of the braconid larval parasitoid, Apanteles militaris Walsh. in its host larvae, Pseudaletia unipuncta (Haworth) was observed as a result of the death of its host infected with Neoaplictana carpocapsae before the parasitoid could complete its development. However, when the parasitized larvae were treated with the nematode late (11 days after parasitism), 94\% of the parasitoid larvae emerged from the host and formed normal pupae. The treated cocoons, however, were found to be resistant to nematode infection [30]. In contrast, investigating the pathogenicity of $S$. 
scapterisci to larvae and pupae of the tachinid, Ormia deplete (Wied.), a parasitoid of the mole cricket, Scapteriscus vicinus Scudder (Orth.: Gryllotalpidae) revealed that $\%$ emergence of parasitoid adults from treated larvae and pupae did not differ significantly from the control [31].

S. carpocapsae caused high rates of mortality in Cardiochelis diaphaniae (Marsh) larvae, a braconid larval parasitoid of the melon worm, Diaphania halinata (L.). However, the pupae in their cocoons were resistant to infection [32]. The susceptibility of larvae, pupae and adults of the braconid ecto-larval parasitoid, Bracon hylobii Ratz. to $H$. downesi (both are natural enemies of the pine weevil, Hylobius abietis (L.) was tested [33]. When the nematode was applied on the parasitoid larvae feeding on its host larvae, the nematode readily infected such parasitoid larvae and there was a reduction in cocoon formation and fewer cocoons gave rise to adults. When the parasitoid cocoons were treated with the nematode, nearly all emerging adults were killed by the nematode infection. The $3^{\text {rd }}$ instar larvae of $S$. littoralis (parasitized with the braconid, Microplitis rufiventris (Kok.)) were treated with H. bacteriophora and S. carpocapsae (1200 IJs/5 parasitized larva/Petri-dish) harboring the egg stage, mid $1^{\text {st }}, 3^{\text {rd }}$ and late $3^{\text {rd }}$ instars of the parasitoid [34]. It was found that the percentages of hosts that gave rise to adult parasitoids after treatment with $S$. carpocapsae were 12, 11, 16 and $53 \%$ for egg, mid $1^{\text {st }}, 3^{\text {rd }}$ and late $3^{\text {rd }}$ instar of the parasitoid on host larvae, respectively. The respective values for $H$. bacteriophora were $0.0,0.0,0.0$ and 52\%.

The interactions between the nematode, $S$. carpocapsae and 2 ichneuminid ecto-larval parasitoids: Mastrus ridibundus (Grav.) and Liotryphon caudatus (Ratz.) of the codling moth (CM), Cydia pomonella (L.). was investigated [35]. Exposing the middle-aged developing larvae of the parasitoids within C. pomonella cocoons to the nematode at a concentration of $10 \mathrm{IJs} / \mathrm{cm}^{2}$ in Petri-dishes (10 larvae/dish) resulted in 70.7 and $85.2 \%$ mortality in $M$. ridibundus and $L$. caudatus, respectively. However, the diapausing full-grown larvae of both parasitoids were almost completely protected from IJs penetration within their own tight cocoons. Percentage of mortality in adults of Necremnus artynes (Walker), an eulophid larval parasitoid of tomato leafminer, Tuta absoluta (Mayrick), treated with $S$. carpocapsae (at a concentration of $50 \mathrm{IJs} / \mathrm{cm}^{2}$ of a plant leaf containing 5 adults did not differ significantly from untreated adults [16].

\subsubsection{Discrimination between Healthy and Nematode-Infected Host}

The females of the parasitoid, Digliphus begini Ashmead were unable to discriminate between $S$. carpocapsae-infected and non-infected Liriomyza trifolii larvae. [36]. Similarly, the female of the ecto-parasitoid, Habrobracon hebetor exposed to larvae of Plodia interpunctella infected with $H$. indica together with healthy larvae did not discriminate between the two [37]. In contrast, the female of the braconid ecto-larval parasitoid, Bracon hylobii Ratz. did not oviposit on the $H$. downesi-infected pine weevil larvae, Hylobius abietis $1-7$ days before exposing to the parasitoid [33]. Similarly, the females of 2 ichneuminid ecto-larval parasitoids: Mastrus ridibundus (Grav.) and Liotryphon caudatus 
(Ratz.) of the codling moth (CM), Cydia pomonella (L.) were able to detect and avoid depositing eggs in $S$. carpocapsae-treated cocooned CM larvae as early as $12 \mathrm{~h}$ post treatment. When given the choice between untreated cocooned CM larvae and those treated with nematode $\left(25 \mathrm{IJs} / \mathrm{cm}^{2}\right.$, equal to $\mathrm{LC}_{95}$ for $\mathrm{CM}$ larvae) 12, 24 and $48 \mathrm{~h}$ earlier, the female parasitoids preferred, significantly, the untreated ones [35].

\subsubsection{Combined Effect of Parasitoids and EPNs on the Host}

A higher percent of mortality occurred in larvae of Liriomyza trifolii (Burgess) when the eulophid parasitoid, Digliphus begini Ashmead was released combined with $S$. carpocapsae [36]. In contrast, investigation of the compatibility of larval parasitoids and $S$. feltiae in controlling the leaf-miner, Liriomyza huidobrensis (Blanchard) indicated that larvae, in their mines, already parasitized by Diglyphus isaea (Walker) or Dancus sibirica (Maklin) were found to be infected with $S$. feltiae following a foliar application of the nematode [38]. In addition, tests to investigate the utilization of $D$. isaea following foliar application of the nematode revealed that adult parasitoids did not discriminate between healthy and nematode-infected larvae for feeding [38].

The potential of integrating the application of $H$. indica and releasing the parasitoid, Habrobracon hebetor (Say) for the management of the Indian meal moth, Plodia interpunctella (Hubner) was studied [37]. It was found that the combination of the nematode and parasitoid increased \% mortality of the insect larvae. Release of the parasitoid or application of the nematode (200 IJs/larva) alone caused $62 \%$ and $71 \%$ mortality, respectively, in Plodia larvae whereas combination of both resulted in $99 \%$ mortality. The nematode was found to be virulent to the parasitoid larvae but not to pupae or adults. The nematode IJs preferred infecting parasitized larvae compared to non-parasitized ones.

\subsection{Field Experiments}

In field experiments, the nematodes, $S$. carpocapsae and $H$. downesi did not affect the natural populations of the parasitoid, Bracon hylobii developing on $\mathrm{Hy}^{-}$ lobius abietis [39]. Similarly, application of $H$. bacteriophora for controlling the Caribbean fruit fly, Anastrepha suspensa (Loew) did not affect, significantly, the population densities of Diachusmimorpha longicaudata Ashmead, a braconid larval parasitoid of A.suspensa [40]. It seems that $H$. bacteriophora could be more promising when combined with $D$. longicaudata for the control of Caribbean fruit fly.

\section{Discussions}

Direct treatment of predators with EPNs in laboratory revealed that some species were found to be highly susceptible to infection [8] [17] [18] [19] [20] and others showed resistance [10]-[16]. However, the European earwig, Furficula auricularia, was found to be resistant to $S$. scapterisci [12] and highly susceptible to $S$. carpocapsae [20]. Also, the staphilinid predator, Dalotia coriaria was re- 
ported to be resistant to $S$. feltiae [13] [14] while the staphilinid, Philonthus $s p$. was susceptible to $H$. bacteriophora and $S$. carpocapsae [8]. Similarly, Chrysoperla carnea proved to be highly susceptible to $S$. carpocapsae and H. bacteriophora [19] while C. zastrophi sillemi was resistant to $H$. bacteriophora [15]. Laboratory studies revealed that the earwig, Labidura riparia was resistant to $S$. carpocapsae and H. bacteriophora [11] while in an experiment in a cabbage field both nematodes did not affect its population [11]. On the other hand, predators consume nematode-infected prey, with no negative effects on their biological parameters, and, in addition, soil predators may feed on the free-living infective juveniles. Thus, such predators may negatively reduce the populations of the EPNs in the environment.

Mostly, parasitoids cannot complete their development inside or on nematode-infected hosts if parasitism occurs before or early after infection [10] [29] [30] [32] [33] [34] [35]. However, the tachinid, Ormia deplete (Wied.), could develop successfully in its host, the mole cricket, Scapteriscus vicinus Scudder (Orth.: Gryllotalpidae) [31]. The parasitoid females may avoid laying eggs in the infected hosts [33] [35] or cannot discriminate between healthy and infected hosts [36] [37]. Two field experiments indicated that the combination of parasitoids and nematodes did not affect, significantly, the populations of the parasitoids [39] [40].

EPNs are applied mainly in the field as bio-control agents against soil-dwelling insects, insects in cryptic habitats, insects pupate in soil as well as insects drop in soil for shade in hot weather (as noticed with Spodoptera spp. and the red palm weevil) [41]. Thus, it can be claimed that the combination of EPNs and parasitoids or predators is expected to have a considerable role in IPM programs against insect pests with no probable contact or effect on such natural enemies on the aerial parts of the plants. Further field studies should be done to obtain enough and reliable information concerning this claim.

\section{Conflicts of Interest}

The author declares no conflicts of interest regarding the publication of this paper.

\section{References}

[1] Beline, T. (2018) Entomopathogenic Nematodes as Biocontrol Agents of Insect Pests in Orchards. CAB Reviews, 13, Article No. 058.

http://www.cabi.org/cabreviews https://doi.org/10.1079/PAVSNNR201813058

[2] Ferguson, K.I. and Stiling, P. (1996) Non-Additive Effects of Multiple Natural Enemies on Aphid Populations. Oecologia, 108, 375-379. https://doi.org/10.1007/BF00334664

[3] Gauglar, R. and Kaya, H.K. (1990) Entomopathogenic Nematodes in Biological Control. CRC Press Inc., Boca Raton, 365 p.

[4] Poinar Jr., G.O. (1990) Taxonomy and Biology of Steinernematidae and Heterorhabditidae. In: Gauglar, R. and Kaya, H.K., Eds., Entomopathogenic Nematodes in Biological Control, CRC Press, Boca Raton, 23-61. 
[5] Georgis, R. (1992) Present and Future Prospects for Entomopathogenic Nematode Products. Biocontrol Science and Technology, 2, 83-99. https://doi.org/10.1080/09583159209355222

[6] Akhurst, R.J. (1990) Safety to Non-Target Invertebrates of Nematodes of Economically Important pests. In: Laird, L.A., Lacey, E.W. and Davidson, E.W., Eds., Safety of Microbial Insecticides, CRC Press, Boca Raton, 233-240.

[7] Kaya, H.K. and Gauglar, R. (1993) Entomopathogenic Nematodes. Annual Review of Entomology, 38, 181-206. https://doi.org/10.1146/annurev.en.38.010193.001145

[8] Georgis, R. and Hague, N.G.M. (1991) Nematodes as Biological Insecticides. Pesticide Outlook, 2, 29-32.

[9] Abbas, M.S.T. (2020) Interactions between Entomopathogenic Fungi and Entomophagous Insects. Advances in Entomology, 8, 130-146.

https://doi.org/10.4236/ae.2020.83010

[10] Mracek, Z. and Spitzer, K. (1983) Interaction of Predators and Parasitoids of the Sawfly, Cephalcia abietis (Pamphilidae: Hymenoptera) with Its Nematode Steinernema kraussei. Journal of Invertebrate Pathology, 42, 397-399. https://doi.org/10.1016/0022-2011(83)90181-7

[11] Georgis, R., Kaya, H.K. and Gauglar, R. (1991) Effect of Steinernematid and Heterorhabditid Nematodes (Rhahditida: Steinernematidae and Heterorhahditidae) on Nontarget Arthropods. Environmental Entomology, 20, 815-822.

https://doi.org/10.1093/ee/20.3.815

[12] Grewal, P.S., Gauglar, R., Kaya, H.K. and Wustly, M. (1993) Infectivity of the Entomopathogenic Nematode, Steinernema scapterisci (Nematoda: Steinernematidae). Journal of Invertebrate Pathology, 62, 22-28. https://doi.org/10.1006/jipa.1993.1069

[13] Jandricic, S., Scott-Dupree, C.D., Broadbent, A.B., Harris, C.R. and Murphy, G. (2006) Compatibility of Atheta coriaria with Other Biological Control Agents and Reduced-Risk Insecticides Used in Greenhouse Floriculture Integrated Pest Management Programs for Fungus Gnats. The Canadian Entomologist, 138, 712-722. https://doi.org/10.4039/n05-106

[14] Tourtois, J. and Grieshop, M.J. (2015) Susceptibility of Dalotia coriaria (Kraatz) (Coleoptera: Staphylinidae) to Entomopathogenic Nematodes (Rhabditida: Heterorhabditidae and Steinernematidae). Insects, 6, 224-235. https://doi.org/10.3390/insects6010224

[15] Lalitha, Y., Nagesh, M. and Jalali, S.K. (2012) Intraguild Predation and Biosafety of Entomopathogenic Nematode, Heterorhabditis bacteriophora Poinar et al., and Its Bacterial Symbiont, Photorhabdus luminescens, to Parasitoid, Trichogramma chilonis Ishii and Predator Chrysoperla zastrowi sillemi (Esben, Petersen). Journal of Biological Control, 26, 334-340.

[16] Lopez, D.G. (2015) Susceptibility of Predators and Parasitoids Used in Biological Control of Tuta absoluta to Foliar Application of Steinernema carpocapsae. https://www.researchgate.net/publication/281742246

[17] Farag, N.A. (2002) Impact of Two Entomopathogenic Nematodes on the Ladybird Coccinella undecim punctata and Its Prey, Aphis fabae. Annals of Agricultural Sciences, 47, 431-443.

[18] Powell, J.R. and Webster, J.M. (2004) Interguild Antagonism between Biological Controls: Impact of Entomopathogenic Nematode Application on an Aphid Predator, Aphidoletes aphidimyza. Biological Control, 30, 110-118. https://doi.org/10.1016/j.biocontrol.2003.09.006

[19] Rojht, H., Kac, M. and Trdan, S. (2009) Nontarget Effect of Entomopathogenic 
Nematodes on Larvae of Twospotted Lady Beetle (Coleoptera: Coccinellidae) and Green Lacewing (Neuroptera: Chrysopidae) under Laboratory Conditions. Journal of Economic Entomology, 102, 1440-1443. https://doi.org/10.1603/029.102.0406

[20] Hodson, A.K., Friedman, M.L., Wu, L.N. and Lewis, E.E. (2011) European Earwig (Forficula auricularia) as a Novel Host for the Entomopathogenic Nematode Steinernema carpocapsae. Journal of Invertebrate Pathology, 107, 60-64. https://doi.org/10.1016/j.jip.2011.02.004

[21] Premachandra, W.T., Borgemeister, C., Berndet, O., Ehler, R.U. and Poehling, H.M. (2003) Combined Releases of Entomopathogenic Nematodes and the Predatory Mite Hypoaspis aculeifer to Control Soil-Dwelling Stages of Western Flower Thrips Frankliniella occidentalis. Bio-Control, 48, 529-541.

[22] Saito, T. and Brownbridge, M. (2016) Compatibility of Soil-Dwelling Predators and Microbial Agents and Their Efficacy in Controlling Soil-Dwelling Stages of Western Flower Thrips Frankliniella occidentalis. Biological Control, 92, 92-100. https://doi.org/10.1016/j.biocontrol.2015.10.003

[23] Lordan, J., Alegre, S., Alins, G., Sarasua, M.J., Morton, A. and Garsia-del Pino, F. (2014) Compatibility between Forficula auricularia and Entomopathogenic Nematodes to Be Used in Pome Fruit Pest Management. Journal of Applied Entomology, 138, 635-643. https://doi.org/10.1111/jen.12118

[24] Mertz, N.R., Sales, F.S., Agudelo, A.J. and Junior, A.M. (2015) Effects of Entomopathogenic Nematodes on the Predator, Calosoma granulatum in the Laboratory. Journal of Insect Behavior, 28, 312-327. https://doi.org/10.1007/s10905-015-9503-7

[25] Baur, M.E., Kaya, H.K. and Strong, D.R. (1998) Foraging Ants as Scavengers on Entomopathogenic Nematode-Killed Insects. Biological Control, 12, 231-236. https://doi.org/10.1006/bcon.1998.0635

[26] Ekmen, Z.I., Hazir, S., Cakmak, I. and Kay, H.K. (2010) Potential Negative Effects on Biological Control by Sancassania polyphyllae (Acari: Acaridae) on an Entomopathogenic Nematode Species. Biological Control, 54, 166-171. https://doi.org/10.1016/j.biocontrol.2010.05.004

[27] Ulug, D., Hazir, S., Kaya, H.K. and Lewis, E. (2014) Natural Enemies of Natural Enemies: The Potential Top-Down Impact of Predators on Entomopathogenic Nematodes Populations. Ecological Entomology, 39, 462-469.

https://doi.org/10.1111/een.12121

[28] Mohan, S. and Sabir, N. (2005) Biosafety Concerns on the Use of Photorhabdus luminescens as Biopesticide: Experimental Evidence of Mortality in Egg Parasitoid Trichogramma spp. Current Science, 89, 1268-1272.

[29] Kaya, H.K. (1984) Effect of the Entomogenous Nematode Nemplectana carpocapsae on the Tachinid Parasite Compsilura concinnata (Diptera: Tachinidae). Journal of Nematology, 16, 9-13.

[30] Kaya, H.K. (1978) Interaction between Neoaplectana carpocapsae (Nematoda: Steinernematidae) and Apanteles militaris (Hymenoptera: Bracondiae), a Parasitoid of the Armyworm, Pseudaletia unipuncta. Journal of Invertebrate Pathology, 31, 358-364. https://doi.org/10.1016/0022-2011(78)90229-X

[31] Parkman, J.P. and Frank, J.H. (2002) Interactions between Ormia depleta (Diptera: Tachinidae) and Steinernema scapterisci (Nematoda: Steinernematidae), Natural Enemies of Pest Mole Crickets (Orthoptera: Gryllotalpidae). Environmental Entomology, 31, 1226-1230. https://doi.org/10.1603/0046-225X-31.6.1226

[32] Shannang, H.K. and Capinera, J.L. (2000) Interference of Steinernema carpocapsae (Nematoda: Steinernematidae) with Cardiochiles diaphaniae (Hymenoptera: Bra- 
conidae), a Parasitoid of Melonworm and Pickleworm (Lepidoptera: Pyralidae). Environmental Entomology, 29, 612-617.

https://doi.org/10.1603/0046-225X-29.3.612

[33] Everard, A., Griffin, C.T. and Dillon, A.B. (2009) Competition and Intraguild Predation between the Braconid Parasitoid Bracon hylobii and the Entomopathogenic Nematode Heterorhabditis downesi, Natural Enemies of the Large Pine Weevil, Hylobius abietis. Bulletin of Entomological Research, 99, 151-161.

https://doi.org/10.1017/S0007485308006287

[34] Atwa, A.A., Hegazi, A.M., Khafagi, W.A. and Abd El-Aziz, G.M. (2013) Interaction of the Koinobiont Parasitoid Microplitis rufiventris of the Cotton Leafworm, Spodoptera littoralis, with Two Entomopathogenic Rhabditids, Heterorhabditis bacteriophora and Steinernema carpocapsae. Journal of Insect Science, 13, 84-91. https://doi.org/10.1673/031.013.8401

[35] Lacey, L., Unruh, T.R. and Headrick, H.L. (2003) Interactions of Two Idiobiont Parasitoids (Hymenoptera: Ichneumonidae) of Codling Moth (Lepidoptera: Tortricidae) with the Entomopathogenic Nematode Steinernema carpocapsae (Rhabditida: Steinernematidae). Journal of Invertebrate Pathology, 83, 230-239. https://doi.org/10.1016/S0022-2011(03)00102-2

[36] Sher, R.B., Parrella, M.P. and Kaya, H.K. (2000) Biological Control of the Leafminer Liriomyza trifolii (Burgess): Implications for Intraguild Predation between Diglyphus begini Ashmead and Steinernema carpocapsae (Weiser). Biological Control, 17, 155-163. https://doi.org/10.1006/bcon.1999.0794

[37] Mbata, G.N. and Shapiro-Ilan, D. (2010) Compatibility of Heterorhabditis indica (Rhabditida: Heterorhabditidae) and Habrobracon hebetor (Hymenoptera: Braconidae) for Biological Control of Plodia interpunctella (Lepidoptera: Pyralidae). Biological Control, 54, 75-82. https://doi.org/10.1016/j.biocontrol.2010.04.009

[38] Head, J., Palme, L.F. and Walters, K.F.A. (2003) The Compatibility of Control Agents Used for the Control of the South American Leafminer, Liriomyza huidobrensis. Biocontrol Science and Technology, 13, 77-86.

https://doi.org/10.1080/0958315021000054403

[39] Dillon, A.B., Moore, C.P., Downes, M.J. and Griffin, C.T. (2008) Managing Populations of the Large Pine Weevil, Hylobius abietis, Using Bottom-Up and Top-Down Approach. Forest Ecological Management, 255, 2634-2642.

https://doi.org/10.1016/j.foreco.2008.01.021

[40] Heve, W.K., Carrillo, D., Kora, F.E. and Dunkan, L.W. (2017) Increasing Entomopathogenic Nematode Biodiversity Reduces Efficacy against the Caribbean Fruit Fly Anastrepha suspensa: Interaction with the Parasitoid Diachasmimorpha longicaudata. Journal of Pest Science, 91, 799-813. https://doi.org/10.1007/s10340-017-0942-0

[41] Abbas, M.S.T., Hanounik, S.B., Mousa, S.A. and Al-Bagham, S.H. (2000) Soil Application of Entomopathogenic Nematodes as a New Approach for Controlling Rhynchophorus ferrugineus on Date Palm. International Journal of Nematology, 10, 215-218.

\section{Abbreviations}

Entomopathogenic nematodes (EPNs)

Infective juveniles (IJs) 